\title{
Pentoxifylline decreases tumor necrosis factor and interleukin-1 during high tidal volume
}

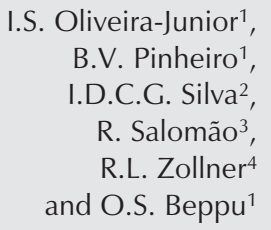

I.S. Oliveira-Junior ${ }^{1}$, B.V. Pinheiro ${ }^{1}$, I.D.C.G. Silva ${ }^{2}$, R. Salomão ${ }^{3}$, R.L. Zollner ${ }^{4}$ and O.S. Beppu ${ }^{1}$

\author{
'Disciplina de Pneumologia, ${ }^{2}$ Laboratório de Ginecologia Molecular, and \\ ${ }^{3}$ Laboratório de Imunologia, Departamento de Doenças Infecciosas e Parasitárias, \\ Universidade Federal de São Paulo, São Paulo, SP, Brasil \\ ${ }^{4}$ Disciplina e Laboratório de Imunologia Clínica, Departamento de Clínica Médica, \\ Universidade Estadual de Campinas, Campinas, SP, Brasil
}

\section{Correspondence \\ O.S. Beppu \\ Laboratório de Pesquisa Experimental em Pneumologia \\ Departamento de Pneumologia UNIFESP \\ Rua Pedro de Toledo, 781, 4 andar 04039-032 São Paulo, SP Brasil \\ E-mail: itamarjr@pneumo.epm.br}

Publication supported by FAPESP.

Received November 14, 2002 Accepted August 25, 2003

\begin{abstract}
Tumor necrosis factor-alpha (TNF- $\alpha$ ) is one of the most important proinflammatory cytokines which plays a central role in host defense and in the acute inflammatory response related to tissue injury. The major source of TNF- $\alpha$ are immune cells such as neutrophils and macrophages. We tested the hypothesis that pentoxifylline, a methylxanthine derivative, down-regulates proinflammatory cytokine expression during acute lung injury in rats. Male Wistar rats weighing 250 to $450 \mathrm{~g}$ were anesthetized i $p$ with $50 \mathrm{mg} / \mathrm{kg}$ sodium thiopental and randomly divided into three groups: group $1(\mathrm{~N}=7)$ : tidal volume $\left(\mathrm{V}_{\mathrm{T}}\right)=7 \mathrm{ml} / \mathrm{kg}$, respiratory rate $(\mathrm{RR})=50$ breaths $/ \mathrm{min}$ and normal saline infusion; group $2(\mathrm{~N}=7): \mathrm{V}_{\mathrm{T}}=42 \mathrm{ml} / \mathrm{kg}, \mathrm{RR}=9$ breaths $/ \mathrm{min}$ and normal saline infusion; group $3(\mathrm{~N}=7): \mathrm{V}_{\mathrm{T}}=42 \mathrm{ml} / \mathrm{kg}, \mathrm{RR}=9$ breaths/min and pentoxifylline infusion. The animals were ventilated with an inspired oxygen fraction of 1.0, a positive end-expiratory pressure of $3 \mathrm{cmH}_{2} \mathrm{O}$, and normal saline or pentoxifylline injected into the left femoral vein. The mRNA of TNF- $\alpha$ rapidly increased in the lung tissue within 180 min of ventilation with a higher $\mathrm{V}_{\mathrm{T}}$ with normal saline infusion. The concentrations of inflammatory mediators were decreased in plasma and bronchoalveolar lavage (BAL) in the presence of higher $\mathrm{V}_{\mathrm{T}}$ with pentoxifylline infusion (TNF- $\alpha$ : plasma, 102.2 \pm 90.9 and BAL, $118.2 \pm 82.1$; IL-1ß: plasma, $45.2 \pm 42.7$ and BAL, $50.2 \pm 34.9, \mathrm{P}<0.05)$. We conclude that TNF- $\alpha$ produced by neutrophil influx may function as an alert signal in host defense to induce production of other inflammatory mediators.
\end{abstract}

\section{Introduction}

In clinical disorders such as acute respiratory distress syndrome (ARDS), asthma, sepsis and shock, regardless of the underlying insults, the host initiates an inflammatory
Key words

- Tumor necrosis factor-alpha

- Pentoxifylline

- Inflammation

- Acute lung injury response with the release of numerous mediators, in particular, proinflammatory cytokines which may potentiate organ injury. However, depending on the ventilatory strategy, mechanical ventilation itself can either perpetuate or worsen previous lung injury. 
Various experimental studies have demonstrated that mechanical ventilation with high tidal volumes $\left(\mathrm{V}_{\mathrm{T}}\right)$ and/or high transpulmonary pressures causes lung injury (1-4). Studies on lung lavage have shown increased levels of tumor necrosis factor-alpha (TNF$\alpha$ ), interleukins (IL)-1ß, -6 and -10 , interferon- $\gamma$ and thromboxane $\beta 2$, suggesting an ongoing pulmonary inflammatory response (4-6) that is often associated with the migration of neutrophils to the lung (7).

Pentoxifylline (PTX), a phosphodiesterase inhibitor, has hemorheologic activity thought to be based on its ability to reduce blood viscosity, decreases serum levels of TNF- $\alpha$, increases the filtrability of blood cells and it is widely used for treatment of immune function. This drug has been shown to attenuate the symptoms of endotoxin shock and ARDS and is used clinically in the management of vascular diseases, especially microcirculatory dysfunction (8). In addition to acting as an anti-inflammatory agent, it can also suppress the synthesis of TNF- $\alpha$ by monocytes and lung macrophages (9-16). Studies using PTX have demonstrated leukocyte inhibition (17), and a decreased production of superoxide anions and release of granular enzymes from neutrophils (18-20). Experimental studies on endotoxemia in animals have shown that pretreatment with PTX improves the survival rate. In ARDS-simulating experimental studies, pretreatment with PTX or its administration after induction of the pathological state results in inhibited protein extravasation and sequestration of neutrophils (21-23).

Due to these anti-inflammatory properties and supported by experimental studies, PTX was used for the treatment of patients with ARDS, a condition in which inflammatory mediators and neutrophils are known to play an important role in the genesis of lung injury (24). However, the results have been disappointing (25), indicating that a better understanding of both the mechanisms underlying ventilator-induced lung injury (VILI) and the effect of PTX on this condition is required.

We tested the hypothesis that treatment with PTX can attenuate VILI by reducing the production of inflammatory cytokines and thus acute lung injury. We used a rat model of VILI and observed that PTX administration reduced lung edema, histological endothelial injury, lung neutrophil migration and cytokine response under high $\mathrm{V}_{\mathrm{T}}$ ventilation, suggesting that PTX may be useful for the treatment of VILI.

\section{Material and Methods}

\section{Animal preparation}

The study was approved by the Institutional Research Ethics Committee of the Federal University of São Paulo (UNIFESP/ EPM; \#014/00), São Paulo, SP, Brazil. All animals received humane care in compliance with the "Principles of Laboratory Animal Care" formulated by the National Society for Medical Research (USA), the "Guide for the Care and Use of Laboratory Animals" prepared by the Institute of Laboratory Animal Resources, published by the National Institutes of Health (USA), and with the "Guidance on the Operation of the Animals (Scientific Procedures) Act 1986" published by Her Majesty's Stationery Office, London, England.

Male Wistar rats weighing 250 to $450 \mathrm{~g}$ were anesthetized ip with $50 \mathrm{mg} / \mathrm{kg}$ sodium thiopental (Thionembutal, Abbott, São Paulo, SP, Brazil). Muscle relaxation was maintained with $0.8 \mathrm{mg} / \mathrm{kg}$ pancuronium bromide, ip (Pavulon, Organon, São Paulo, SP, Brazil). The animals received either a high dose $(50 \mathrm{mg} / \mathrm{kg})$ of PTX $\left(\right.$ Trental $^{\circledR}$, Hoechst Marion Roussel, São Paulo, SP, Brazil) or normal saline at $100 \mathrm{mg} / \mathrm{kg}$ (in bolus) injected into the caudal vein. A continuous PTX or normal saline infusion (50 $\mathrm{mg} \mathrm{kg}^{-1}$ $\mathrm{h}^{-1}$ ) with a syringe pump model ' 11 ' (Single Syringe 55-1111, Harvard Apparatus, 
Holliston, MA, USA) was administered after surgical preparation as described below.

Surgical preparation. Tracheostomy was performed and a 14-G cannula was inserted into the trachea. The sterile catheter, PE-50 tubing (Intramedic Polyethylene Tubing, Becton Dickinson, Jersey City, NJ, USA), was inserted into the left internal carotid artery for the determination of blood gases $\left(\mathrm{PaO}_{2}\right.$ and $\left.\mathrm{PaCO}_{2}\right)$ and $\mathrm{pH}$ (ABL-330, Radiometer, Copenhagen, Denmark), and the left femoral vein was cannulated for PTX or normal saline infusion.

\section{Experimental protocol and measurements}

The rats were divided into three groups, one receiving PTX and two receiving normal saline. Group $1(\mathrm{G} 1)$ : the rats $(\mathrm{N}=7)$ were ventilated with a low volume ventilation $\left(\mathrm{V}_{\mathrm{T}}=\right.$ $7 \mathrm{ml} / \mathrm{kg}$, positive end-respiratory pressure $(\mathrm{PEEP})=3 \mathrm{cmH}_{2} \mathrm{O}$, respiratory rate $(\mathrm{RR})=$ 50 breaths $/ \mathrm{min}$, inspiratory flow $=20 \mathrm{ml} / \mathrm{s}$ ) with normal saline infusion for $180 \mathrm{~min}$; group $2(\mathrm{G} 2)$ : the rats $(\mathrm{N}=7)$ were ventilated with a high volume ventilation $\left(\mathrm{V}_{\mathrm{T}}=42 \mathrm{ml} /\right.$ $\mathrm{kg}, \mathrm{PEEP}=3 \mathrm{cmH}_{2} \mathrm{O}, \mathrm{RR}=9$ breaths $/ \mathrm{min}$, inspiratory flow $=20 \mathrm{ml} / \mathrm{s}$ ) with normal saline infusion for $180 \mathrm{~min}$; group 3 (G3): the rats $(\mathrm{N}=7)$ were ventilated with a high volume ventilation $\left(\mathrm{V}_{\mathrm{T}}=42 \mathrm{ml} / \mathrm{kg}\right.$, PEEP $=$ $3 \mathrm{cmH}_{2} \mathrm{O}, \mathrm{RR}=9$ breaths/min, inspiratory flow $=20 \mathrm{ml} / \mathrm{s}$ ) with PTX infusion for 180 min.

Initial mechanical ventilation. During the first period the rats were initially ventilated for 20 min with a $V_{T}$ of $7 \mathrm{ml} / \mathrm{kg}$ and an $\mathrm{RR}$ of 50 breaths/min, PEEP of $3 \mathrm{cmH}_{2} \mathrm{O}$, inspiratory flow of $20 \mathrm{ml} / \mathrm{s}$ and an inspired oxygen fraction of 1.0, in a time-cycled ventilator (Intermed, São Paulo, SP, Brazil) adapted for small animals. At the end of this ventilatory period, arterial blood gases were regulated to target an arterial oxygen pressure $\left(\mathrm{PaO}_{2}\right) \geq 400 \mathrm{mmHg}$ before the experiment was started. Airway pressure was measured with an MP 45 pressure transducer (Validyne
Engineering Corp., Nortbridge, CA, USA), connected to the tracheostomy cannula, and the signal was recorded continuously on a strip chart recorder. $\mathrm{V}_{\mathrm{T}}$ was estimated with a small type pneumotachograph (Pneumotach, Hans Rudolf Inc., Kansas City, KS, USA) connected to an MP $45 \pm 2 \mathrm{cmH}_{2} \mathrm{O}$ transducer.

Arterial blood gases. $\mathrm{PaO}_{2}$ and $\mathrm{PaCO}_{2}$ and $\mathrm{pH}$ were measured with an automatic analyzer at 20,30, 90 and $180 \mathrm{~min}$ after the initiation of mechanical ventilation.

Pressure-volume curve. At the end of the experiment (post-ventilation) the abdomen was opened and a blood sample was obtained from the inferior vena cava. The animal was sacrificed, and a pressure-volume curve was determined ( $\mathrm{N}=7$ /group) as previously described (26) by inflating/deflating the lungs with 0.5 - to $1-\mathrm{ml}$ aliquots of atmospheric air (with a water column) to a maximal transpulmonary pressure of $30 \mathrm{cmH}_{2} \mathrm{O}$.

Bronchoalveolar lavage (BAL). The right lung was washed three times with $30 \mathrm{ml} / \mathrm{kg}$ normal saline $(0.9 \% \mathrm{NaCl})$ at $4^{\circ} \mathrm{C}$. The cell pellets were resuspended and a 1-ml aliquot was separated for cell counting. The cell pellets were centrifuged at $1,500 \mathrm{~g}$ for 10 min at $4^{\circ} \mathrm{C}$ using a model 5415R Eppendorf centrifuge (Hamburg, Germany) and the supernatant was stored at $-80^{\circ} \mathrm{C}$ for further measurements.

Protein leakage. Protein concentration was determined spectrophotometrically in duplicate by the method of Lowry et al. (27) in the aliquots of the BAL.

Cell differentiation. The total cell number in BAL fluid was counted with a hemocytometer (Neubauer chamber). The pellet was spun in a LABHO, model CT 120 centrifuge (São Paulo, SP, Brazil) at $530 \mathrm{~g}$ for $10 \mathrm{~min}$. A differential cell count of 200 cells was obtained by light microscopy (Carl Zeiss, Axiolab, Jena, Germany) with a digital color camera (Hyper HAD, Sony Inc., New York, NY, USA).

Cytokine assay. Cytokine concentrations 
in plasma and BAL were measured with specific commercially available enzymelinked immunosorbent assay (ELISA) kits according to manufacturer instructions. The kit for TNF- $\alpha$ (Factor-test-x/RAT TNF- $\alpha$ ) was from Genzyme (Cambridge, MA, USA) and the kit for IL- $1 \beta$ was from R\&D Systems (Minneapolis, MN, USA). The sensitivity of the kits for TNF- $\alpha$ and IL- $1 \beta$ was 10 and 5 $\mathrm{pg} / \mathrm{ml}$, respectively.

Tissue preparation for the reverse transcription-polymerase chain reaction ( $R T$ $P C R$ ). A lung homogenate was obtained from each group (G1, G2 and G3). mRNA for TNF- $\alpha$ expression and glyceraldehyde-3phosphate dehydrogenase (GAPDH, housekeeping gene) was determined semiquantitatively by RT-PCR. Cytoplasmic RNA was extracted from rat lung using the Trizol total RNA isolation kit (Gibco-BRL, Gaithersburg, MD, USA). The amount of RNA was quantified by absorbance at $260 \mathrm{~nm}$. Sample quality was checked by running the RNA on $1.5 \%$ agarose gels.

Total RNA $(1 \mu \mathrm{g})$ from each sample was reverse transcribed into cDNA using oligo (dT) as a primer. PCR conditions were 32 cycles of denaturation at $94^{\circ} \mathrm{C}$ for $40 \mathrm{~s}$ and annealing at $55^{\circ} \mathrm{C}$ for $30 \mathrm{~s}$ using a GeneAmp PCR System 9700 thermocycler (Perkin Elmer, Norwalk, CT, USA). The primers for TNF- $\alpha$ [AF269159] were: sense, 5'-TCA GCC TCT TCT CAT TCC TGC-3'/antisense, 5'-GTG CAG CAT CGT TTG GTG GTT-3' and the primers for GAPDH were: sense, 5'GTG AAG GTC GGT GTG AAC GGA TTT-3'/antisense, 5'-CAC AGT CTT CTG AGT GGC AGT GAT-3'. The GAPDH signals were used to control for variation in the efficiency of RNA extraction, reverse transcription, and PCR.

The PCR products were separated by electrophoresis on $2 \%$ agarose gel containing $0.2 \mu \mathrm{l} / \mathrm{ml}$ ethidium bromide. The PCR products were visualized with an M26 transilluminator (BioAgency, São Paulo, SP, Brazil) at $302 \mathrm{~nm}$, the membrane was scanned, the resulting images were captured, and the results were analyzed with Kodak Digital Science EDAS 120 software (Eastman Kodak Company, Rochester, NY, USA). The relative expression of TNF- $\alpha$ mRNA was calculated as the ratio of the densities of the TNF- $\alpha$ and GAPDH bands.

\section{Statistical analysis}

Data are reported as means \pm SD and were collected and analyzed using the SPSS statistical software (SPSS 10.0, SPSS Science, Chicago, IL, USA). Data were also analyzed by one-way ANOVA followed by the Tukey-Kramer test. Repeated measures analysis of variance was used for $\mathrm{PaO}_{2}$, $\mathrm{PaCO}_{2}$ and $\mathrm{pH}$. A P value $<0.05$ or $5 \%$ was considered statistically significant.

\section{Results}

All animals survived the protocol. The pressure-volume curves obtained with 10 and $20 \mathrm{cmH}_{2} \mathrm{O}$ were lower in the $\mathrm{G} 2$ group than in the G1 group. PTX pretreatment (G3) resulted in pressure-volume curves higher than normal saline (G2) for the same ventilation volume $\left(\mathrm{V}_{\mathrm{T}}=42 \mathrm{ml} / \mathrm{kg}\right)$ (Table 1$)$. Increased $\mathrm{V}_{\mathrm{T}}$ induced a striking leakage of proteins (G1 vs G2), a finding partially reversed by PTX treatment (Table 1).

BAL cellularity (cells $/ \mathrm{mm}^{3}$ ) was significantly higher $(\mathrm{P}<0.0001)$ in the G2 group compared with the G1 and G3 groups. The G2 group showed a lower percentage of macrophages and a higher percentage of neutrophils compared to the G1 and G3 groups (Table 1).

During the first 20-min period of mechanical ventilation all variables regarding arterial blood gases were similar among the groups. $\mathrm{PaO}_{2}$ decreased in animals with higher $\mathrm{V}_{\mathrm{T}}(42 \mathrm{ml} / \mathrm{kg}, \mathrm{G} 2)$ after 90 and 180 min of mechanical ventilation, a dysfunction prevented by PTX treatment (G3) (Table 2). No differences in $\mathrm{PaCO}_{2}$ or $\mathrm{pH}$ were found 
among the groups during the 20- and 30-min period of mechanical ventilation, but $\mathrm{pH}$ decreased in animals with higher $\mathrm{V}_{\mathrm{T}}$ in the $\mathrm{G} 2$ and $\mathrm{G} 3$ groups compared to the G1 group (Table 2).

TNF- $\alpha$ levels measured in plasma and BAL (Figure 1A and B) were higher in animals ventilated with a higher volume $(\mathrm{G} 2$ : plasma, $1987.5 \pm 100.2$ and BAL, $1144.6 \pm$ $272.7 \mathrm{pg} / \mathrm{ml}$ ) than in those ventilated with a low volumes (G1: plasma, 177.2 \pm 21.1 and BAL, $225.8 \pm 28.1 \mathrm{pg} / \mathrm{ml})$. PTX treatment (G3: plasma, $102.2 \pm 90.9$ and BAL, $118.2 \pm$ $82.1 \mathrm{pg} / \mathrm{ml}$ ) prevented the release of TNF- $\alpha$ induced by a higher ventilatory volume in both plasma and BAL (Figure 1A and B).

Table 1. Effect of pentoxifylline on total cell count, macrophages, neutrophils and total protein in bronchoalveolar lavage, wet-to-dry ratio (W:D), and transpulmonary pressure (Tp) in 10 and $20 \mathrm{cmH}_{2} \mathrm{O}$.

\begin{tabular}{lccr}
\hline & G1 & G2 & G3 \\
\hline Total cells (cells/mm $)$ & $81.42 \pm 18.17$ & $159.14 \pm 42.25$ & $113.14 \pm 11.71$ \\
Macrophages (\%) & $65.00 \pm 5.5$ & $24.7 \pm 9.7$ & $57.5 \pm 9.9$ \\
Neutrophils (\%) & $15.7 \pm 6.4$ & $60.7 \pm 10.0$ & $26.3 \pm 6.0$ \\
Total protein (mg) & $9.38 \pm 0.90$ & $52.67 \pm 9.32$ & $25.69 \pm 2.24$ \\
W:D (g) & $8.77 \pm 1.22$ & $10.58 \pm 1.34$ & $8.29 \pm 1.53$ \\
$\operatorname{Tp}\left(10 \mathrm{cmH}_{2} \mathrm{O}\right)$ & $5.57 \pm 1.90$ & $4.86 \pm 1.12$ & $7.71 \pm 1.38$ \\
$\operatorname{Tp}\left(20 \mathrm{cmH}_{2} \mathrm{O}\right)$ & $13.00 \pm 2.45$ & $11.71 \pm 2.21$ & $15.57 \pm 1.81$ \\
\hline
\end{tabular}

Data are reported as mean \pm SD for 7 animals in each group. Infusion rate of pentoxifylline and normal saline: $50 \mathrm{mg} \mathrm{kg}^{-1} \mathrm{~h}^{-1}$.

Total cell count $=\mathrm{G} 1$ vs $\mathrm{G} 2(\mathrm{P}<0.001)$ and $\mathrm{G} 2$ vs $\mathrm{G} 3(\mathrm{P}<0.05)$.

Macrophages $=\mathrm{G} 1$ vs $\mathrm{G} 2(\mathrm{P}<0.001)$ and $\mathrm{G} 2$ vs $\mathrm{G} 3(\mathrm{P}<0.001)$.

Neutrophils $=\mathrm{G} 1$ vs $\mathrm{G} 2(\mathrm{P}<0.001)$ and $\mathrm{G} 2$ vs $\mathrm{G} 3(\mathrm{P}<0.001)$

Total protein $=\mathrm{G} 1$ vs $\mathrm{G} 2(\mathrm{P}<0.001), \mathrm{G} 1$ vs $\mathrm{G} 3(\mathrm{P}<0.001)$ and $\mathrm{G} 2$ vs $\mathrm{G} 3(\mathrm{P}<0.001)$.

$\mathrm{W}: \mathrm{D}=\mathrm{G} 2$ vs $\mathrm{G} 3(\mathrm{P}<0.0143)$.

$\mathrm{Tp}\left(10 \mathrm{cmH}_{2} \mathrm{O}\right)=\mathrm{G} 1$ vs $\mathrm{G} 2(\mathrm{P}>0.05), \mathrm{G} 1$ vs $\mathrm{G} 3(\mathrm{P}<0.05)$ and $\mathrm{G} 2$ vs $\mathrm{G} 3(\mathrm{P}<0.01)$.

$\mathrm{Tp}\left(20 \mathrm{cmH}_{2} \mathrm{O}\right)=\mathrm{G} 1$ vs $\mathrm{G} 2(\mathrm{P}>0.05), \mathrm{G} 1$ vs $\mathrm{G} 3(\mathrm{P}>0.05)$ and $\mathrm{G} 2$ vs $\mathrm{G} 3(\mathrm{P}<0.05)$ (ANOVA).

Table 2. Arterial blood gases of rats during mechanical ventilation in the presence and absence of pentoxifylline.

\begin{tabular}{|c|c|c|c|c|c|c|c|c|c|c|c|}
\hline \multicolumn{3}{|c|}{$20 \mathrm{~min}$} & \multicolumn{3}{|c|}{$30 \mathrm{~min}$} & \multicolumn{3}{|c|}{$90 \mathrm{~min}$} & \multicolumn{3}{|c|}{$180 \mathrm{~min}$} \\
\hline G1 & G2 & G3 & G1 & G2 & G3 & G1 & $\mathrm{G} 2$ & G3 & G1 & G2 & G3 \\
\hline \multicolumn{12}{|l|}{$\mathrm{PaO}_{2}(\mathrm{mmHg})$} \\
\hline 517.1 & 517.1 & 505.6 & 512.0 & 572.8 & 569.5 & 517.9 & 408.5 & 587.0 & 542.8 & 190.5 & 615.8 \\
\hline \pm 44.1 & \pm 53.6 & \pm 44.6 & \pm 49.8 & \pm 37.5 & \pm 41.6 & \pm 59.1 & \pm 81.1 & \pm 38.3 & \pm 38.2 & \pm 65.4 & \pm 26.0 \\
\hline \multicolumn{12}{|c|}{$\mathrm{PaCO}_{2}(\mathrm{mmHg})$} \\
\hline 41.8 & 46.1 & 41.9 & 43.2 & 46.6 & 44.3 & 44.5 & 40.5 & 38.8 & 43.2 & 41.7 & 42.3 \\
\hline \pm 4.8 & \pm 9.6 & \pm 8.7 & \pm 6.8 & \pm 7.59 & \pm 7.44 & \pm 10.5 & \pm 9.5 & \pm 10.8 & \pm 4.7 & \pm 12.3 & \pm 10.8 \\
\hline \multicolumn{12}{|l|}{$\mathrm{pH}$} \\
\hline 7.4 & 7.4 & 7.3 & 7.4 & 7.4 & 7.3 & 7.5 & 7.4 & 7.3 & 7.3 & 7.3 & 7.2 \\
\hline \pm 0.09 & \pm 0.04 & \pm 0.09 & \pm 0.05 & \pm 0.05 & \pm 0.08 & \pm 0.13 & \pm 0.07 & \pm 0.07 & \pm 0.05 & \pm 0.08 & \pm 0.05 \\
\hline
\end{tabular}

PTX $(50 \mathrm{mg} / \mathrm{kg}$ ) was administered $\mathrm{iv}$. The arterial blood gases are reported as means \pm SD for 7 animals in each group.

$\mathrm{PaO}_{2}(10 \mathrm{~min})-\mathrm{G} 1$ vs $\mathrm{G} 2(\mathrm{P}<0.05) . \mathrm{PaO}_{2}(90 \mathrm{~min})-\mathrm{G} 1$ vs $\mathrm{G} 2(\mathrm{P}<0.05)$, and $\mathrm{G} 2$ vs $\mathrm{G} 3(\mathrm{P}<0.001) . \mathrm{PaO}_{2}(180$ $\mathrm{min})$ - $\mathrm{G} 1$ vs $\mathrm{G} 2(\mathrm{P}<0.001)$, $\mathrm{G} 1$ vs $\mathrm{G} 3(\mathrm{P}<0.05)$, and $\mathrm{G} 2$ vs $\mathrm{G} 3(\mathrm{P}<0.001)$.

pH (90 min) - G1 vs G3 (P<0.05). pH (180 min) - G1 vs G3 $(P<0.05)$, and $G 2$ vs $G 3(P<0.05)$ (repeated measures ANOVA).

$\mathrm{PaCO}_{2}$ did not differ significantly between groups. 
Figure 1. Effect of pentoxifylline (PTX) on TNF- $\alpha$ levels in plasma (A) and bronchoalveolar lavage (B) of rats under mechanical ventilation. Data are reported as means $\pm S D$. G1 $\left(V_{T}=7 \mathrm{ml} / \mathrm{kg}\right.$ with normal saline infusion; $\mathrm{N}=$ 7); $\mathrm{G} 2\left(\mathrm{~V}_{\mathrm{T}}=42 \mathrm{ml} / \mathrm{kg}\right.$ with normal saline infusion; $N=7$ ), and $\mathrm{G} 3\left(\mathrm{~V}_{\mathrm{T}}=42 \mathrm{ml} / \mathrm{kg}\right.$ with PTX infusion $(50 \mathrm{mg} / \mathrm{kg}) ; N=7)$. $A$, * $P<$ 0.001 for $\mathrm{G} 2$ vs $\mathrm{G} 1$ vs $\mathrm{G} 3$. $B$, ${ }^{*} \mathrm{P}$ $<0.001$ for $\mathrm{G} 2$ vs G1 vs G3 (ANOVA).

Figure 2. Effect of pentoxifylline (PTX) on IL-1ß levels in plasma (A) and bronchoalveolar lavage (B) of rats under mechanical ventilation. Data are reported as means $\pm S D . G 1\left(V_{T}=7 \mathrm{ml} / \mathrm{kg}\right.$ with normal saline infusion; $N=$ 7): $\mathrm{G} 2\left(\mathrm{~V}_{\mathrm{T}}=42 \mathrm{ml} / \mathrm{kg}\right.$ with normal saline infusion; $N=7$ ), and $\mathrm{G} 3\left(\mathrm{~V}_{\mathrm{T}}=42 \mathrm{ml} / \mathrm{kg}\right.$ with PTX infusion $(50 \mathrm{mg} / \mathrm{kg}) ; \mathrm{N}=7)$. $A$, ${ }^{*} \mathrm{P}<$ 0.001 for $\mathrm{G} 2$ vs $\mathrm{G} 1$ vs $\mathrm{G} 3$. B , *P $<0.001$ for $\mathrm{G} 2$ vs G1 vs G3 (ANOVA).
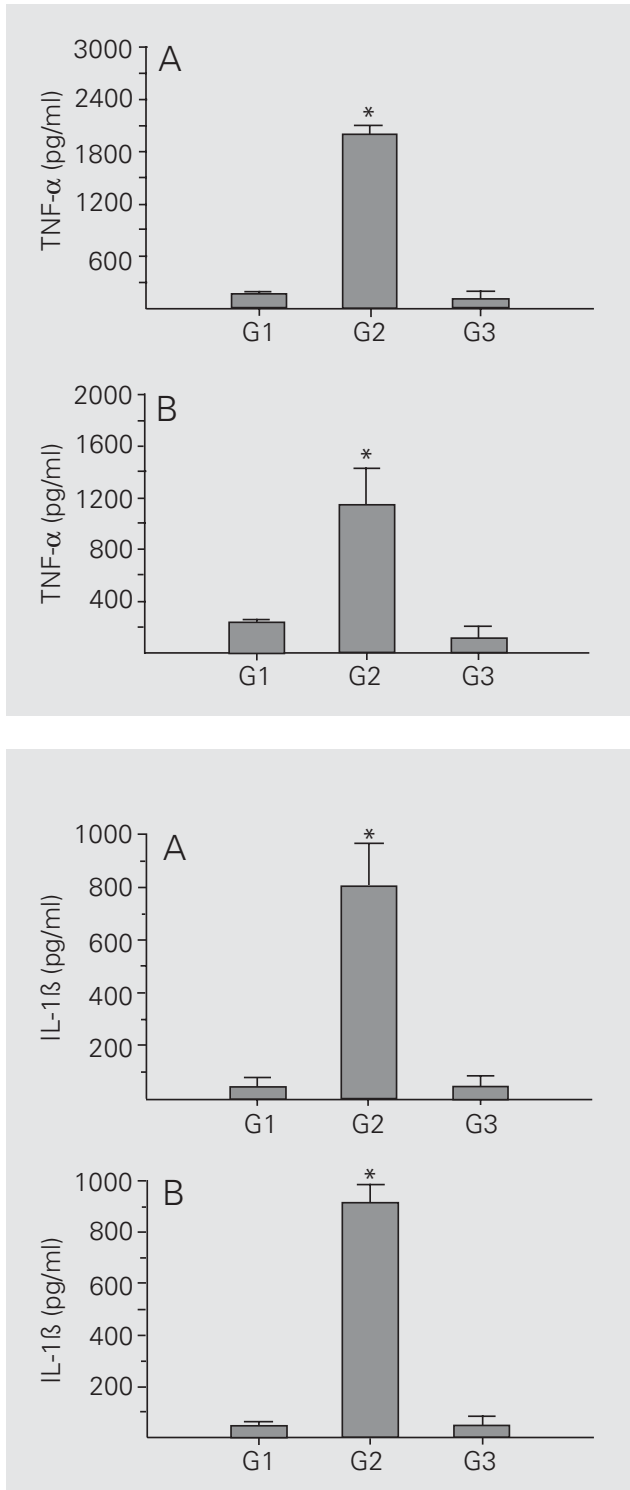

Similar results were obtained for IL-1ß levels measured in plasma and BAL in G1 (plasma: $44 \pm 32.2$ and BAL: $48.6 \pm 11.8 \mathrm{pg} /$ $\mathrm{ml}$ ), G2 (plasma: $802.9 \pm 164.4$ and BAL: $914.7 \pm 63.6 \mathrm{pg} / \mathrm{ml}$ ), and G3 (plasma: $45.2 \pm$ 42.7 and BAL: $50.2 \pm 34.9 \mathrm{pg} / \mathrm{ml}$ ) (Figure $2 \mathrm{~A}$ and $\mathrm{B})$.

To examine whether TNF- $\alpha$ synthesis is effectively regulated at the transcriptional level in tissue cells, total extracted RNA and TNF- $\alpha$ mRNA levels were determined by semiquantitative RT-PCR. The mRNA level of TNF- $\alpha$ was low before PTX treatment. As an internal control, there was no change in mRNA level of GAPDH (Figure 3).

\section{Discussion}

Increased epithelial and endothelial permeability and development of pulmonary edema $(7,28)$ in association with the inflammatory response $(6,7,29,30)$ have been demonstrated in animals ventilated with high $\mathrm{V}_{\mathrm{T}}$ and/or high transpulmonary pressure $(7,28)$ and were also observed in the present study. The rats ventilated with high $\mathrm{V}_{\mathrm{T}}$ presented increased protein leakage in addition to severe hypoxemia, as well as a higher number of cells in the BAL, mainly composed of polymorphonuclear neutrophils. The fact that these alterations were attenuated by the administration of PTX clearly demonstrates that this drug exerts a protective effect in this
Figure 3. Effect of tidal volumes on TNF- $\alpha$ mRNA expression in lungs of rats subjected to mechanical ventilation. $\mathrm{G} 1\left(\mathrm{~V}_{\mathrm{T}}=7\right.$ $\mathrm{ml} / \mathrm{kg}$ with normal saline infusion; $\mathrm{N}=7) ; \mathrm{G} 2\left(\mathrm{~V}_{\mathrm{T}}=42 \mathrm{ml} / \mathrm{kg}\right.$ with normal saline infusion; $N=$ 7), and $\mathrm{G} 3\left(\mathrm{~V}_{T}=42 \mathrm{ml} / \mathrm{kg}\right.$ with PTX infusion (50 mg/kg); $N=7$ ). Cellular RNA of lung tissue was harvested 180 min after mechanical ventilation and subjected to semiquantitative RT-PCR. A, TNF- $\alpha ; B$, control glyceraldehyde3-phosphate dehydrogenase (GAPDH); $C$, densitometric analysis of $A+B$.
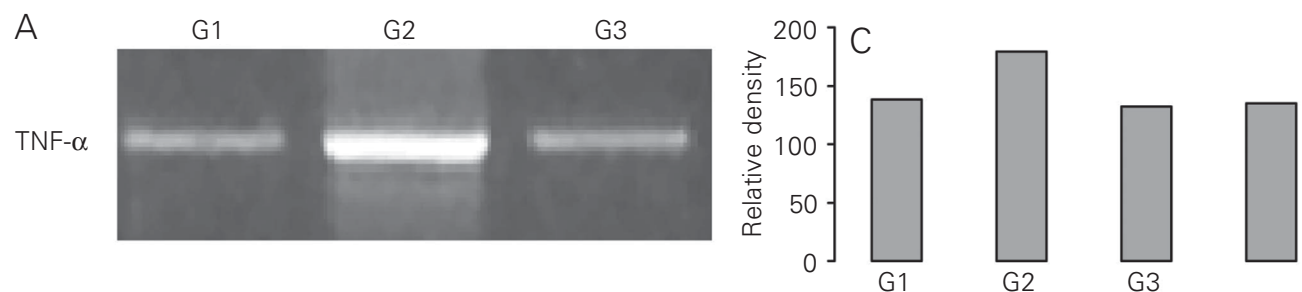

B

TNF- $\alpha$

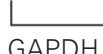


experimental model of ARDS. The mechanism of action of PTX is complex and incompletely understood.

Blood arterial gases obtained during mechanical ventilation showed that high $\mathrm{V}_{\mathrm{T}}$ had a profound impact on $\mathrm{PaO}_{2}$ after 180 min of mechanical ventilation (G1 vs G2). This effect was completely reversed in animals treated with PTX (G3), in agreement with other studies (23). Similarly, high $\mathrm{V}_{\mathrm{T}}$ rats presented an impressive enhancement of total protein in BAL, which was partially reversed by PTX treatment. Increased protein leakage and wet-to-dry weight ratios (Table 1) in these animals could be due to direct physical damage to the barrier or be secondary to enhanced endothelial permeability (31).

Mandell's (24) review of the anti-inflammatory effects of PTX highlights the major actions of this drug on neutrophil function. PTX reduces the production of inflammatory cytokines by stimulated neutrophils and blocks the effect of these cytokines on the other phagocytes. Therefore, PTX decreases the adherence, rigidity, oxidative burst, degranulation, and chemotactic movement of neutrophils. Our study demonstrated that the total cell number in BAL fluid was higher in the $\mathrm{G} 2$ group $(\mathrm{P}<0.0002)$ than in the other groups (Table 1). There was an increased number of neutrophils in the $\mathrm{G} 2$ group $(\mathrm{P}<$ 0.0001 ) and the number of macrophages in the BAL was lower in the G2 group and higher in the G3 group (Table 1). Thus, we have found that PTX interferes with the adhesion and extravasation of leukocytes induced by mechanical ventilation. However, the precise mechanisms underlying such effect are not clear.

The protective effect of PTX observed in our study is supported by previous reports on rats and rabbits. Seear et al. (23) demonstrated in a rabbit lavage model that pretreatment with $20.0 \mathrm{mg} / \mathrm{kg}$ PTX (bolus) followed by continuous infusion of $20.0 \mathrm{mg} \mathrm{kg}^{-1} \mathrm{~h}^{-1}$ reduced lung edema. The cited study indi- cates that PTX reduces edema formation in rabbits after saline lavage, not by lowering microvascular pressure for fluid filtration or by accelerating alveolar fluid reabsorption, but possibly by its anti-inflammatory effect on neutrophil function.

Previous in vivo studies have shown that PTX can decrease lung capillary permeability $(8,17)$. Thus, the present data, taken together with those from previous studies, suggest that PTX attenuates lung injury $(12,23$, 32,33).

Inhibition of chemokine production and intercellular adhesion molecule-1 expression by IL-1, TNF- $\alpha$ and TNF- $\beta$, cytokines with different signal transduction pathways, is likely to occur at the transcriptional level also. However, other post-transcriptional mechanisms might also be involved since PTX blocked the production of chemokines even 2-4 h after proinflammatory cytokine addition. Studies are underway to elucidate the mechanism of action of PTX. TNF- $\alpha$ is believed to play an important role in the inflammatory cascade (34). Studies on animals have demonstrated that overdistension of the lungs by mechanical ventilation can cause elevations in inflammatory cytokines $(35,36)$. Nash et al. (37) examined the distribution of TNF- $\alpha$ in lung tissue from patients dying of ARDS.

The participation of inflammatory cytokines in the course of VILI has been the subject of recent studies. Tremblay et al. (6) examined the effects of different ventilatory strategies on the concentrations of several cytokines in BAL fluid from isolated rat lungs ventilated with different end-expiratory pressures and $\mathrm{V}_{\mathrm{T}}$. The high $\mathrm{V}_{\mathrm{T}}(40 \mathrm{ml} /$ $\mathrm{kg}$ ) with zero-PEEP resulted in considerable increases in TNF- $\alpha$, IL-1 $1 \beta$, and IL- 6 and in macrophage inflammatory protein-2, a chemokine of the IL- 8 family. We have previously shown that mechanical ventilation induces TNF- $\alpha$ secretion, detected in BAL and serum, with higher levels found in animals ventilated with higher $\mathrm{V}_{\mathrm{T}}(38)$. We 
confirmed and expanded these results by showing that high $\mathrm{V}_{\mathrm{T}}$ increases TNF- $\alpha$ mRNA levels and the number of cytokines (TNF- $\alpha$ and IL-1 $\beta$ ) in the plasma and BAL of animals with VILI.

Numerous studies have shown that an increase of intracellular cAMP is caused by phosphodiesterase inhibition by PTX (39). However, there is no consistent correlation between increased blood mononuclear cells (39) and other possible mechanisms as revealed in a recent study showing that PTX can inactivate $\beta 1$ integrins on $T$ cells and inhibit the expression of activation markers CD25, CD69, and CD98 on T lymphocytes stimulated with mitogens (40).

Nevertheless, it is possible that PTX exerts its protective effect by inhibiting the production and secretion of inflammatory cytokines (24). In fact, we found a dramatic reduction in plasma and BAL levels of TNF$\alpha$ and IL- $1 \beta$ in animals treated with PTX, suggesting that the inhibition of these inflammatory mediators may be responsible for the protection mediated by PTX in VILI. The mechanism responsible for the inhibition of TNF production by PTX may involve alteration of the intracellular signaling pathways responsible for gene transcription, since we found decreased TNF- $\alpha$ mRNA expression in tissues of PTX-treated animals com- pared to the controls. Another very interesting question regarding our findings is why the increase in mRNA levels was lower than the increase observed in plasma and BAL. We believe that very likely the production of cytokines might be controlled in a post-transcriptional way so that cytokines are somehow stored inside cells and therefore do not need a very fast and strong gene transcription activity.

The results of the present study have important clinical and research implications in that they emphasize the importance of cellular uptake of a cytokine for the modulation of the inflammatory cell response. Further studies are needed to elucidate the effectiveness of these agents based on their in vivo bioavailability, which will vary based on route of administration and potential toxicity. Understanding the extent to which changes in the redox state of inflammatory cells alter their responses will have important implications for the development of therapeutic strategies to modulate the systemic inflammatory response.

\section{Acknowledgments}

We are indebted to M.K.C. Brunalti, M.A. Custodio, C.A. Pirondi and S. Salaorni for expert technical assistance.

\section{References}

1. McRitchie DI, Isowa N, Edelson JD, Xavier AM, Cai L, Man HY, Wang YT, Keshavjee SH, Slutsky AS \& Liu L (2000). Production of tumour necrosis factor $\alpha$ by primary cultured rat alveolar epithelial cells. Cytokine, 12: 644-654.

2. Kolobow T, Morretti MP, Fumagalli R, Mascheroni $D$, Prato $P$, Chen $V$ \& Joris $M$ (1987). Severe impairment in lung function induced by high peak airway pressure during mechanical ventilation. American Review of Respiratory Disease, 135: 312-315.

3. Dreyfuss D, Soler P, Basset G \& Saumon G (1988). High inflation pressure pulmonary edema: respective effects of high airway pressure, high tidal volume, and positive end-expiratory pressure. American Review of Respiratory Disease, 137: 1159-1165.

4. Oliveira-Junior IS, Rodriguez-Lopez DV \& Beppu OS (2000). Can pentoxifylline improve the ventilator-induced lung injury? American Journal of Respiratory and Critical Care Medicine, 161: A723 (Abstract).
5. Imai YT, Kawano T, Iwamoto S, Nakagawa S, Takata M \& Miyasaka K (1999). Intratracheal anti-tumour necrosis factor-alpha antibody attenuates ventilator-induced lung injury in rabbits. Journal of Applied Physiology, 87: 510-515.

6. Tremblay L, Valenza F, Ribeiro SP, Li J \& Slutsky AS (1997). Injurious ventilatory strategies increase cytokines and c-fos m-RNA expression in an isolated rat lung model. Journal of Clinical Investigation, 99: 944-952.

7. Tsuno K, Prato P \& Kolobow T (1990). Acute lung injury from mechanical ventilation at moderately high airway pressures. Journal of Applied Physiology, 69: 956-961.

8. Belazs C \& Kiss E (1994). Immunological aspects of the effect of pentoxifylline. Acta Microbiologica Academiae Scientiarum Hungaricae, 41: 121-172.

9. Han J, Thompson P \& Beutler B (1990). Dexamethasone and pentoxifylline inhibit endotoxin-induced cachectin/tumour necrosis 
factor synthesis at separate points in the signaling pathway. Journal of Experimental Medicine, 172: 391-394.

10. Doherty GM, Jensen JC, Alexander HR, Buresh CM \& Norton JA (1991). Pentoxifylline suppression of tumour necrosis factor gene transcription. Surgery, 110: 192-198.

11. Zabel P, Schonharting MM, Schade UF \& Schlaak M (1991). Effects of pentoxifylline in endotoxinemia in human volunteers. Progress in Clinical and Biological Research, 367: 207-213.

12. Balibrea-Cantero JL, Arias-Diaz J, Garcia C, Torres-Melero J, Simon C, Rodriguez JM \& Vara E (1994). Effect of pentoxifylline on the inhibition of surfactant synthesis induced by TNF-alpha in human type II pneumocytes. American Journal of Respiratory and Critical Care Medicine, 149: 699-706.

13. Marques LJ, Teschler H, Guzman J \& Costabel U (1997). Smoker's lung transplanted to a nonsmoker. Long-term detection of smoker's macrophages. American Journal of Respiratory and Critical Care Medicine, 156: 1700-1702.

14. Poulakis N, Androutsos G, Kazi D, Bastas A, Provata A, Bitsakou C, Kontozoglou T, Polyzogopoulou C \& Tassiopoulou A (1999). The differential effect of pentoxifylline on cytokine production by alveolar macrophages and its clinical implications. Respiratory Medicine, 93: 52-57.

15. Marques LJ, Zheng L, Poulakis N, Guzman J \& Costabel U (1999). Pentoxifylline inhibits TNF- $\alpha$ production from human alveolar macrophages. American Journal of Respiratory and Critical Care Medicine, 159: 508-511.

16. Zabel P, Entzian P, Dalhoff K \& Schlaak M (1997). Pentoxifylline in treatment of sarcoidosis. American Journal of Respiratory and Critical Care Medicine, 155: 1665-1669.

17. Seiffge D, Bissinger T, Kremer E, Laux V \& Schleyerbach R (1995). Inhibitory effects of pentoxifylline on LPS induced leukocyte adhesion and macromolecular extravasation in the microcirculation. Inflammation Research, 44: 281-286.

18. Currie MS, Rao KM, Padmanabhan J, Jones A, Crawford J \& Cohen HJ (1990). Stimulus-specific effects of pentoxifylline on neutrophil CR3 expression, degranulation, and superoxide production. Journal of Leukocyte Biology, 47: 244-250.

19. Oka Y, Murata A, Nishijima J, Hiraoka N, Yasuda T, Kitagawa K, Ogawa M \& Mori T (1991). Inhibitory effect of pentoxifylline and prostaglandin E1 on the release of neutrophil elastase from FMLPstimulated neutrophils. Journal of Medicine, 22: 371-382.

20. Roberts PJ, Yog KL, Khwaja A, Johnson BV, Pizzey AB, Carver JE, Addison IE \& Linck DC (1993). Pentoxifylline at clinically achievable levels inhibits FMLP induced neutrophil responses, but not priming, upregulation, cell-adhesion molecules, or emigration induced by GM-CSF. European Journal of Haematology, 150: 1-10.

21. Ishizaka A, Wu Z, Stephens KE, Harada H, Hogue RS, O'Hanley PT \& Raffin TA (1988). Attenuation of acute lung injury in septic guineapigs by pentoxifylline. American Review of Respiratory Disease, 138: 376-382

22. Lilly CM, Sandhu JS, Ishizaka A, Harada H, Yonemaru M, Larrick JW, Shi TX, O'Hanlley PT \& Raffin TA (1989). Pentoxifylline prevents tumour necrosis factor-induced lung injury. American Review of Respiratory Disease, 139: 1361-1368.

23. Seear MD, Hannam VL, Kaapa P, Usha Raj J \& O'Brodovich HM (1990). Effect of pentoxifylline on hemodynamics, alveolar fluid reabsorption, and pulmonary edema in a model of acute lung injury. American Review of Respiratory Disease, 142: 1083-1087.

24. Mandell GL (1995). Cytokines, phagocytes and pentoxifylline. Journal of Cardiovascular Pharmacology, 25: S20-S22.
25. Montravers P, Fagon J-Y, Gilbert C, Blanchet F, Novara A \& Chastre $J$ (1993). Pilot study of cardiopulmonary risk from pentoxifylline in adult respiratory distress syndrome. Chest, 103: 1017-1022.

26. Muscedere JG, Mullen JBM, Gan K \& Slutsky AS (1994). Tidal ventilation at low airway pressures can augment lung injury. American Journal of Respiratory and Critical Care Medicine, 149: 1327-1334.

27. Lowry O, Rosebrough NJ, Farr AL \& Randall RJ (1951). Protein measurement with the Folin phenol reagent. Journal of Biological Chemistry, 193: 265-275.

28. Dreyfuss D \& Saumon G (1993). Role of tidal volume, FCR, and endinspiratory volume in the development of pulmonary edema following mechanical ventilation. American Review of Respiratory Disease, 148: 1194-1203

29. Chiumello D, Pristine G \& Slutsky AS (1999). Mechanical ventilation affects local and systemic cytokines in an animal model of acute respiratory distress syndrome. American Journal of Respiratory and Critical Care Medicine, 160: 109-116.

30. Dreyfuss D, Basset G, Soler P \& Saumon G (1985). Intermittent positive pressure hyperventilation with inflation pressures produces pulmonary microvascular injury in rats. American Review of Respiratory Disease, 132: 880-884.

31. Gunther A, Ruppert C, Schmidt R, Markart P, Grimminger F, Walmrath D \& Seeger W (2001). Surfactant alteration and replacement in acute respiratory distress syndrome. Respiratory Research, 2: 353-364.

32. Neuner P, Klosner G, Schauer E, Pourmojib M, MacHeiner C, Grünwald C, Knobler R, Schwars A, Luger TA \& Scharz T (1994). Pentoxifylline in vivo down-regulates the release of IL-1ß, IL-6, IL-8 and tumour necrosis factor-alpha by human peripheral blood mononuclear cells. Immunology, 83: 262-267.

33. Barroso-Aranda J \& Schmid-Schönbein GW (1990). Pentoxifylline pretreatment decreases the pool of circulating activated neutrophils, in vivo adhesion to endothelium, and improves survival from hemorrhagic shock. Biorheology, 27: 401-418.

34. Townsley MI, Korthuis RJ, Rippe B, Parker JC \& Taylor AE (1986). Validation of double vascular occlusion method for Pc,i in lung and skeletal muscle. Journal of Applied Physiology, 61: 127-132.

35. Ehrhart I, McCloud L, Creamer KM \& Ocasio H (1999). Pentoxifylline markedly reduces pulmonary neutrophil sequestration. Chest, 116 (Suppl 1): 34S.

36. Ranieri VM, Suter PM, Tortorella C, De Tulio R, Dayer JM, Brienza A, Bruno F \& Slutsky AS (1999). Effect of mechanical ventilation on inflammatory mediators in patients with acute respiratory distress syndrome: a randomized controlled trial. Journal of the American Medical Association, 282: 54-61.

37. Nash JR, McLaughlin PJ, Hoyle C \& Roberts D (1991). Immunolocalization of tumour necrosis factor alpha in lung tissue from patients dying with adult respiratory distress syndrome. Histopathology, 19: 395-402.

38. Bueno PCS, Bueno CE, Santos ML, Oliveira-Júnior I, Salomão R, Pinheiro BV \& Beppu OS (2002). Ventilation with high tidal volume induces inflammatory lung injury. Brazilian Journal of Medical and Biological Research, 35: 191-198.

39. Gonzalez-Amaro R, Portales-Perez D, Baranda L, Redondo JM, Martinez-Martinez S, Yanes-Mo M, Garcia-Vicuna R, Cabanas C \& Sanches-Madrid F (1998). Pentoxifylline inhibits adhesion and activation of human T lymphocytes. Journal of Immunology, 161: 65-72.

40. Krakauer T (2000). Pentoxifylline inhibits ICAM-1 expression and chemokine production induced by proinflammatory cytokines in human pulmonary epithelial cells. Immunopharmacology, 46: 253-261. 